\title{
Non-Verbal Communication: Why We Need It in Foreign Language Teaching and How We Can Foster It with Drama Activities
}

\author{
Carola Surkamp
}

\begin{abstract}
Even though non-verbal communication is an essential part of communicative situations, it still is a neglected issue in foreign language teaching. This is quite surprising as no language learner can achieve communicative competence without having some knowledge of non-verbal phenomena, which make communication authentic and serve numerous functions needed for communicative success. Teaching a combination of verbal and non-verbal aspects of communication has positive effects on the language learning process in general and on the students' willingness to communicate in particular. Furthermore, it is important for language learners to become aware of the role non-verbal communication plays in intercultural encounters. Additionally, the knowledge and awareness of the functions of non-verbal communication also help to develop literary competence since non-verbal phenomena contribute to a text's meaning and its effect on the reader in both drama and prose. The objectives of this paper are to outline the nature and functions of non-verbal communication, to show why integrating non-verbal phenomena into different areas of FLT can be highly valuable, and to present drama activities that help sensitise students to non-verbal aspects of communication in various contexts.
\end{abstract}

\section{Introduction}

Non-verbal communication plays an important role in human social interaction. In this regard, Abercrombie (1968: 55) states what is generally taken for granted: "We speak with our vocal organs, but we converse with our entire bodies." Every facial expression and every gesture contributes to the overall meaning of a statement. Our body language thus accompanies every speech act we make, and even if we do not speak, our non-verbal behaviour constantly transmits information that can be meaningful.

Birdwhistell (1955), one of the pioneers in research on non-verbal communication, estimates that in a conversation up to $65 \%$ of what is transmitted on 
the social, interpersonal level is conveyed non-verbally. This implies that a considerable part of any message that we are sending and receiving is encoded and decoded non-verbally. Consequently, although only recently, non-verbal phenomena have become a focus of interest in various disciplines such as anthropology, psychology, sociology, and linguistics (cf. Kendon 2004).

In the context of foreign language teaching, however, non-verbal phenomena have not been given sufficient a ttention ( cf. Eßer 2 007: 3 20; Knabe 2007: 13). Language classes have traditionally emphasised verbal communication. Although the Common European Framework of Reference for Languages does at least intermittently pick up on non-verbal communication (cf. 4.4.5), the way this is dealt with does not suffice: the text sporadically refers to body language in terms of pointing, gesture and mime to support the verbal reference-but it does not include a structured and explicit description of non-verbal competences. Most manuals for foreign language teaching similarly do not include materials and exercises which focus on non-verbal forms of communication (cf. Reimann 2012: 36; Özkul 2012: 17).

And yet, several recent publications in the domain of foreign language teaching show that non-verbal forms of communication are very important not only for the teaching of language, but also for intercultural learning (cf. Knabe 2007; Reimann 2008, 2012; Strasser 2008). In addition to this, a variety of methodological work has been published in practice-oriented journals, suggesting different approaches to including non-verbal forms of communication in foreign language classes (cf. Reimann 2000; Bouchara 2009; Özkul 2012).

It is not surprising that these suggestions always include role-plays, mime and other action-oriented and holistic activities that consider the entire body with its different forms of perception and expression. Many of these exercises originate from drama pedagogy and have found their way into foreign language teaching: they stress the value of non-verbal elements for language learning, not only when it comes to creating authentic communicative situations in the classroom, but also as a compensation strategy for listening and speaking as well as in the context of intercultural learning (cf. Schewe 1993: 6f.; Tselikas 1999: 28; Culham 2002; Müller 2008: 28ff.; Elis 2015). Studies in the area of drama pedagogy also draw attention to the fact that non-verbal forms of communication used in acting can prepare learners' verbal communication in the foreign language by helping them get rid of inhibitions (cf. Matthias 2007), and that these forms of communication can motivate learners to communicate in multi-modal ways, making use of different channels and signs (cf. Rothwell 2011). What is missing, however, is a distinction between the various requirements students need to fulfill in the different a reas of foreign language learning (linguistic, literary and intercultural learning) as well as the establishment of a connection between these requirements and selected drama methods.

For this reason, the following article has two aims: First, following a short overview of different non-verbal components of communication, I will show 
how these different components are part of the teaching of language, culture and literature. Second, I want to illustrate how foreign language classes based on drama pedagogy can contribute more effectively to a consideration of non-verbal communication on the different levels of the teaching and learning of a foreign language.

\section{Non-verbal Components of Communication}

Usually, non-verbal communication is defined in opposition to verbal communication: all phenomena with a communicative value that are not part of verbal communication are summarised under the umbrella term 'non-verbal communication'. As the psychologist Scherer (1980: 225) notes, ambiguities in the use of the term can often be traced back to the fact that the term 'non-verbal' refers both to visible phenomena such as gestures and facial expression as well as to audible aspects such as speaking styles and quality of speech. It is for this reason that Scherer (ibid.) proposes making a distinction between vocal and non-vocal phenomena. On the one hand we can, therefore, find paralinguistic (i.e. vocal) phenomena such as individual characteristics of the voice, speech melody, temporal aspects, forms of articulation and side noise. On the other hand, there are non-vocal phenomena in conversation such as the external characteristics of a speaker, physical reactions and a number of kinesic phenomena, which can be divided into macro-kinesic and micro-kinesic phenomena. The following figure shows a systematic overview of the main forms of non-verbal communication (cf. Argyle 1972, 2002; Ekman/Friesen 1969; Crystal 1974; Poyatos 1983):

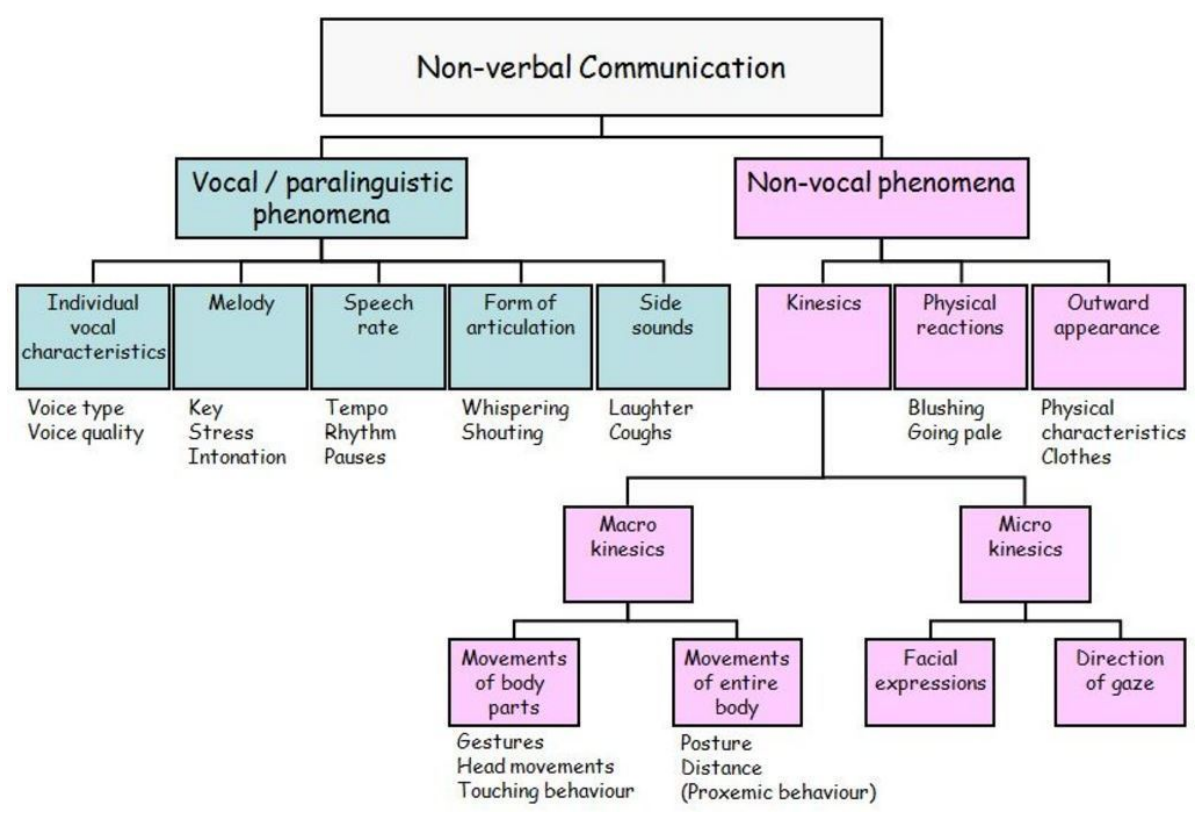

Figure 1: Overview of the main forms of non-verbal communication 
Observing such non-verbal phenomena in conversation plays an important role in the interpretation of meaning, for instance when it comes to assessing others, to the creation of closeness and distance or to understanding the relationship between conversation partners:

First, our physical appearance provides nonverbal cues that others use to make judgments about us. Second, the way we use space [...] helps us regulate intimacy and control our sensory exposure to others. Third, the way we move our bodies [...] provides information about us to others. Fourth, the way we use our voice [...] tells others how we define the relationship between ourselves and them. Fifth, the degree to which we touch others and the degree to which we allow others to touch us provides cues to how we see our relationships. (Gudykunst/Kim 1997: 225)

One has, however, to consider two things (cf. Scherer 1980: 227f.). First, non-verbal signs are not always coded in an unambiguous way. This is due to the fact that not all signs are emblematic, which means that they can be used in different ways by individuals according to the context or specific group. Moreover, there can be cultural differences in the use of one and the same sign. Second, non-verbal signs are not always transmitted in an intentional way, that is, there is not necessarily a specific intention underlying the use of a sign. A large part of non-verbal communication happens unconsciously. The way closeness and distance are established through physical contact between individuals, for instance, is something that usually happens unconsciously, although physical touch can be used intentionally in particular situations, for example the act of shaking somebody's hand when greeting them (cf. Strasser 2008: 65f.).

\section{On the Importance of Non-verbal Communication in Language Teaching}

One of the main teaching objectives in the foreign language classroom is the development of communicative competence. As an essential part of communication is non-verbal, communicative competence cannot consist solely of the correct use of verbal language. The fact that non-verbal phenomena play an essential role in conversation becomes evident when we consider the different functions non-verbal behaviour can fulfil (cf. Jakobson 1960: 353ff.; Ekman/Friesen 1969; Argyle 2002: 106, 117ff.; Strasser 2008: 68ff.). Non-verbal cues may have

- an emotive function in that they (e.g. through facial expression) reveal the speaker's personality, feelings, thoughts and attitudes;

- a conative function in that they (e.g. through body posture) externalise the social roles of and the relationship level (sympathy/antipathy) between two interlocutors; 
- a phatic function in that they regulate conversations and structure interaction (e.g. indicating changes of speakers or the beginning/ending of contributions);

- a function as illustrators of verbal communication: they may anticipate, repeat, contradict, substitute, complement or accentuate the verbal message (e.g., nodding our head to accompany verbal agreement); or lastly,

- a function as emblems with a binding lexical or ritual meaning (e.g., 'V' for victory)

If we leave out the non-verbal dimension of communication in foreign language teaching, we are creating artificial $s$ ituations, which $d \mathrm{o} n$ ot $\mathrm{r}$ eflect real-life encounters between speakers of the foreign language. Students do not learn to coordinate word and action, language and gesture, neither in the reception of the foreign language nor in its production.

Non-verbal behaviour is also relevant as a communicative strategy. Nonverbal communication can help learners both to understand the foreign language and to express themselves in it. Lacking knowledge of vocabulary or not being able to produce speech can be compensated for by the decoding of non-verbal signals or by the transmission of part of the communicative intention to the gesture modality. Similarly, the emotive function of non-verbal behaviour can give students valuable information about the emotions and the intentions of their conversation partner in linguistic emergencies. Making use of the phatic function of non-verbal communication, in addition, can be a strategy for speakers to use their own facial expression and/or gestures in order to give feedback to their conversation partner concerning their reaction to the perceived communicative process or, inversely, to interpret whether the communication is successful or not by decoding their conversation partner's non-verbal behaviour.

Finally, the combination of verbal and non-verbal communication in the foreign language classroom can make it easier for learners to remember new words or grammatical structures. As neurological research has shown, we remember vocabulary and language patterns for a longer period of time if language is linked with non-verbal signs (cf. Knabe 2007: 61).

\section{Non-verbal Communication and Intercultural Learning}

Effective communication in a foreign language is more than just a matter of language proficiency. One of the goals -if not the main goal - of foreign language teaching is to help students to become intercultural speakers. Phenomena such as the direction of gaze or the role of silence are often not the same across cultures. Since they can even convey the complete opposite of what is intended, behavioural patterns are a common source of intercultural misunderstandings: 
In some cultures, for example, gestures play a more prominent role than in others, e.g. Italians use more gestures than Scandinavians. As a result, Scandinavians appear 'wooden' and boring to Italians. [...] Eye contact is also treated differently. For example, most Germans would think East Asians are trying to hide something, or are shifty because respect forbids East Asians from looking their partner directly into the eyes. [...] During a discussion of equals, Arab men tend to raise their voice to express strength and sincerity; an American would consider that to be aggressive and objectionable. (Hinner 1998: 12)

What is considered an appropriate distance between people in a conversation depends on culture, too. Edward Hall (1966) argues that cultures can be differentiated in terms of the degree of contact preferred by their members. Cultures in which people tend to stand close and touch a lot are referred to as high contact cultures, while cultures in which people stand apart and tend not to touch are referred to as low contact cultures. People in high contact cultures consider physical closeness in conversations as positive and distance as negative; in low contact cultures the opposite is often the case (cf. Gudykunst/Kim 1997: 231f.; Knabe 2007: 78f.).

These examples indicate that the greatest obstacles to successful intercultural communication are very often not linguistic mistakes. Though grammar or vocabulary errors can make conversation difficult, they seldom inhibit the communication process. Violations in non-verbal behaviour normally entail more serious consequences: many intercultural misunderstandings and even communication breakdowns are due to the behaviour of a person from one culture being 'inappropriately' perceived, interpreted, and reacted to by someone from another culture (cf. Culham 2002: 95f.). This is particularly true for homomorphy, that is, one and the same gesture being used as an emblem in different cultures but carrying significantly different meanings (cf. Knabe 2007: 86f.; Strasser 2008: 74). Burgoon et al. (1989: 27, 189) point out that the use of different non-verbal signs by political leaders can even lead to geopolitical embarrassment:

A prime example is when then vice president Richard Nixon undertook a good-will tour to Latin America. Photographers at his first airport stop flashed pictures of Nixon holding up both hands in the 'A-OK' gesture. Unfortunately, that gesture in many Latin American countries means 'screw you' [...].

Therefore, the teaching of intercultural communicative competence should include non-verbal communication. Learners of foreign languages must be made aware of the impact culture has on vocal and non-vocal phenomena. This implies that they should explore and develop an awareness of the conventional behaviour in common situations in their own culture (cf. Strasser 2008: 75). This is particularly obvious in the case of so-called 'culturemes', that is, specific forms of behaviour such as how to treat guests, table manners, giving and receiving presents etc., that play a role in every culture, but that are often 
expressed through different non-verbal behaviour, so-called 'behavioremes' (cf. Oksaar 1988 in Eßer 2007: 327).

But integrating cultural aspects into the teaching of body language does not primarily mean prompting the students to memorise the patterns of non-verbal behaviour which speakers of another language follow. Rather, students need to develop sufficient sensitivity to the impact of culturally-induced behaviour on communication. When others offend our non-verbal expectations, we tend to assess these offenses negatively. Recognizing that there are essential cultural differences in the use of body language permits students to respond more effectively when intercultural communication breaks down. They must learn to view problems in intercultural communication as a result of cultural differences rather than, taking their own cultural perception as a rule, as some sort of insufficiency on the part of the other speaker.

There is yet another advantage that the integration of non-verbal communication has to offer in fostering intercultural competence. Just as non-verbal behaviour can have a strategic function for verbal learning processes, components of non-verbal communication can be used in intercultural interactions for soothing tensions between speakers, e.g. by expressing an open and attentive attitude towards one's conversation partner by means of facial expressions or a certain physical posture. The fact that, aside from culture-specific signs, there are also a number of physical expressions that are interpreted identically in every culture, helps to support the idea of using non-verbal communication to increase mutual understanding (cf. Strasser 2008: 70).

\section{Non-verbal Communication in the Literature Classroom}

Non-verbal aspects are also important for the understanding and interpretation of literary texts. When characters interact with each other, they also act non-verbally, and these components can fulfill functions in literary dialogues that are similar to their real-life counterparts. The following example from the young adult novel Face by Benjamin Zephaniah illustrates that the characters' body language (in italics here) both reveals their feelings (a pretentious show of self-confidence by Mark that results in surprise and insecurity; a show of self-confidence by Jennifer who is older and more experienced) and allows readers to draw conclusions about their relationship to each other (Jennifer's superiority, Mark's capitulation):

On this particular afternoon Mark's eye was caught by Jennifer Hamilton from Year 11. She was sixteen years old, and a lot taller than him.

Mark whistled to her and shouted so that everyone could hear, 'Come 'ere, Jenny baby, and give us a kiss goodbye.'

She walked straight up to him, looked down on him and said, 'I'm here, boy, let's do it.'

Mark was shocked. 'OK, you start it,' he spluttered. 
'What, do you want me to start without you?' Laughter burst out as spectators gathered around [...]. Jennifer stood towering above Mark like a gladiator. Mark got himself into more trouble every time he spoke. 'I tell ya what, close yu eyes and I'll start.' 'Close my eyes. What's the matter, boy? Don't you want me to see you?' [...] The laughter got louder. [... E Even Jennifer cracked a smile when one of her best friends shouted, 'Don't hurt him, have mercy upon his lips, for he is young and fragile.' 'All right.' Mark got serious. 'Bend down and let's do the business.'

As Jennifer bent down towards him, Mark squeezed his eyes shut, every muscle on his face tensed, his feet gripping the floor. Jennifer put her hand under his chin and tilted his face towards the sky, the crowd sounding like supporters at a boxing match. Jennifer stuck out her tongue and unleashed it all over Mark's forehead. The crowd roared with laughter. (Zephaniah 1999: 10f.)

Beyond everyday functions, body language in fictional t exts s erves specific aesthetic purposes. Non-verbal phenomena described in literary texts, enacted in plays or shown in films, function as aesthetic signs: they can - as the example shows - convey important information concerning the characters and they can increase the authenticity of interactions (cf. also Korte 1993).

On the one hand, working with literary texts in the foreign language classroom can thus help illustrate the general importance and the different functions non-verbal means of expression have in everyday life. On the other hand, teaching literature requires dealing with the way non-verbal communication can fulfill a esthetic f unctions in literary texts a nd the w ay it c reates certain effects on readers or viewers. The ability to approach literary texts accordingly is part of literary competence; a competence that learners need in order to access literary texts in the foreign language and to the worlds they create (cf. Surkamp 2012). Many students have difficulty, for e xample, in speculating about the motives of the characters, let alone in describing and interpreting the creative use of narrative, dramatic of filmic d evices. Their understanding of literature is often limited and restricted to being able to follow a text's plot. Interpreting a literary text, however, does not stop at students reading the text and analysing its verbal codes. In the case of a play, for example, students must be enabled to view the text as a script written for the staging of the play. This performance dimension of stage plays, however, can only be illustrated by considering the non-verbal elements included in the text. This is discussed further below.

\section{Interim Conclusion}

As described above, non-verbal communication in its different forms and functions plays an important role in the three areas of foreign language teaching mentioned. The examples described also show that one can distinguish between 
different dimensions of non-verbal communicative competence ${ }^{1}$ :

- knowledge of different forms of non-verbal behaviour

- knowledge of different functions of non-verbal behaviour

- knowledge of culture-specific non-verbal expressions

- knowledge of aesthetic functions of non-verbal communication in literary texts

- ability to recognise non-verbal behaviour in communicative situations

- awareness of the importance of non-verbal communication in processes of interaction

- awareness of the way body language is shaped by cultures and of differences between cultures

- openness and appreciation for unknown non-verbal forms of behaviour

- strategic use of non-verbal communication in interactions with others

\section{Teaching non-verbal communication through drama activities}

There are a variety of methods that can be used in order to practise different forms and functions of non-verbal communication in the foreign language classroom. These include the use of images (e.g. advertising poster) and audio-visual material, as well as action-orientated methods such as role-plays, video-conferences with speakers of the target language or real-life meetings during school exchanges. It is not surprising that drama activities potentially offer particular opportunities to foster non-verbal communicative competence, as they involve movement and demand the performance of language encounters in a holistic way.

The mere fact that drama activities might increase awareness of non-verbal forms of expression, however, is of little help when it comes to the actual lesson planning. For teachers to be able to select suitable drama activities, it must be clear which areas of foreign language teaching and which dimension of non-verbal communication are meant to be focused on at a particular time. In addition, one must not forget that no methodological approach can (or needs

\footnotetext{
${ }^{1}$ Eßer (2007: 328) uses this term, too: „Um mit einer interkulturellen Begegnungssituation sowohl auf der Perzeptions- als auch der Aktionsebene besser umgehen zu können, brauchen die InteraktionspartnerInnen - neben Empathie und Ambiguitätstoleranz - Einsicht in die Kulturgebundenheit sprachlichen und körpersprachlichen Handelns, neben kommunikativer Kompetenz also auch körpersprachliche Kompetenz.“
} 
to) achieve every potential goal at the same time. In the context of fostering non-verbal communicative competence, for instance, it is important for learners of foreign languages to be familiar with different bodily forms of expression when producing as well as understanding the foreign language. They should be able to listen to native speakers and they should also be able to see them while they are communicating in the foreign language. For this reason, the use of drama activities should be combined with additional materials (e.g. images, films or audio texts) and with different methodological approaches (e.g. a classroom discussion for reflecting on the non-verbal forms of communication used or observed in a drama activity).

Since the learning of foreign languages is too often approached in a purely cognitive way and without physical movements, the teaching of non-verbal communication should first of all offer learners the opportunity to develop an awareness of their own body and its manifold forms of expression. They should, likewise, be supported in letting go of their inhibitions about the use of their body language. These goals are important for all areas of foreign language learning and all sub-dimensions of non-verbal communicative competence. Depending on the aspect of body language that is focused on (non-vocal phenomena such as gestures, mime or moving around, or vocal phenomena like speech melody or speech rate), individual drama activities can be subsumed under specific categories.

Exercises that pay particular attention to non-vocal phenomena make learners concentrate on their bodies and encourage them to use their facial expressions and gestures as a means of communication. The following activities are examples of these types of exercises (cf. Karbowska-Hayes 1984: 16ff.; Maley/Duff 2001; Culham 2002; Waegner 2003 and Nünning/Surkamp 2010: 175ff.):

- Walking around the room: learners are asked to walk around the classroom and adapt their movements to the instructions given by the teacher (e.g. Move as if walking in very high-heeled shoes. / Move as if walking through mud in heavy boots. / Move as if walking barefoot over hot sand on the beach. / Walk as if being followed and feeling nervous. etc.).

- Mirror game: two learners face each other. One of them makes a certain gesture or facial expression. The other one, standing opposite, tries to imitate this behaviour like a mirror. Everyday activities such as brushing one's teeth, putting on make-up, brushing one's hair or getting dressed can be performed as well.

- Guessing professions: the students form a big circle and take turns going into the middle in order to present a profession or an activity using pantomime. The other students try to guess the right answer.

- Identifying freeze frames: the students build a freeze frame for a topic or a situation (e.g. a family picture / a marriage in a church / a talkshow / 
an operating theatre / a rollercoaster) in groups, which must be identified by the others.

- Guessing emotions: three learners stand in front of the group and are given the task to perform a certain emotion (impatience, sadness, boredom, nervousness, happiness, etc.) in an exaggerated way through gestures and mimic. The first learner in the line should show the respective emotion subtly and the other two learners should increase the intensity of the emotion accordingly (e.g. through a stronger facial expression and/or more body language). The other learners have the task of guessing the emotion represented.

An exercise that encourages learners to focus on their voice and the use of different vocal forms of communication is the line improvisation (cf. Nünning/Surkamp 2010: 178f.). Two students stand a few meters apart and then approach each other slowly by alternately placing one foot forward. Both of them are given a word or a sentence that they utter with every step, e.g. player A "I"/Player B: "You", Player A: "Give me back my book". / Player B: "I wouldn't dream of it". These words or sentences should be uttered using different intonations, volume, tone, speech rate, etc.

This drama activity is designed to introduce students to different forms of vocal communication. Since the non-verbal means of expression are combined with verbal ones, however, this activity can also be used to achieve specific linguistic aims, such as an increased awareness of the meaning-generating function of vocal expression in communication. The learners experience, for instance, that a change of word stress can result in a change of meaning, helping them realise that certain moods can influence communicative intentions (cf. Schewe 1993: 175). Likewise, communicative patterns such as 'to win someone over', 'to shoot something down', 'begging', 'rejecting', 'insisting' or 'making concession' can be made audible through vocal phenomena (cf. Müller 1992: 368).

Furthermore, different forms of drama activities such as performing a dialogue, doing role-plays or improvising can help students to increasingly develop an awareness of the meaning of non-verbal communication in processes of interaction. At the same time, they can teach students to pay attention to their own body language and to make strategic use of non-verbal forms of expression (e.g. if their ability to express themselves verbally is limited). In these drama activities, the foreign language is employed in interaction, requiring not only the use of verbal, but also non-verbal means of communication - for production as well as for reception. Drama methods invite learners to coordinate statements made verbally with gestures, facial expressions and body movements. What is also significant here is that performing drama activities makes students adapt their speech rate to the respective situation and vary their tone and intonation in order to give their statement a specific meaning or to avoid misunderstandings. Another advantage of drama methods lies in the way they integrate the use of language into a particular situation requiring a specific, often non-verbally 
expressed behaviour, e.g. the attitude towards the conversation partner, the display of attention, the reaction to what has been said before. In this way, different situations are being performed and different, non-verbal patterns of behaviour can be recognised, interpreted, tried out and maybe even practised in a playful manner through drama activities.

With a view to fostering intercultural learning, drama activities are especially productive when it comes to making students conscious of their own, culturespecific gestures and these activities can also be used to encourage a comparison of other cultural areas. To this end, Reimann (2012: 38) proposes an exercise in which learners use their body language in order to show how specifically intended messages are stressed through gestures in their own culture. In this activity, the teacher illustrates differences to be found in the cultural area of the target language, either with the help of visual material or by performing them. In a further step, learners create their own scene in which some of the newly learned gestures occur. According to Reimann, comparing Germany and France can be done by representing intended messages such as 'about/approximately', 'great', 'bad', 'be quiet!', 'it stinks!' for which different forms of non-verbal communication can be contrasted (cf. also Knabe 2007: 98). The main aim of such endeavours, however, is not so much the precise practising of non-verbal forms of expressions used in other cultures. Instead, the goal is to foster an open attitude towards those signals of body language that might appear strange to learners. Moreover, they can experience the importance of transmitting the intended message of their own cultural signals in intercultural encounters through additional verbal elements (cf. Strasser 2008: 80).

If a learning group consists of students who come from different cultures, it can also be useful to do contrasting pantomimic exercises to make students aware of culture-specific differences in non-verbal communication. In such exercises, individual groups of students are asked to pantomime a specific feeling or an intended message. The rest of the students are observers who have the task of noting differences in the non-verbal representation (cf. Tomalin/Stempleski 1993: 106). In a subsequent discussion, the learners concern themselves with the way both the production and interpretation of body language adheres to culture. By doing this, the similarities between different cultures, e.g. in the representations and perception of emotions (cf. Eßer 2007: 324f.), should be taken into account as well.

When it comes to the teaching of literature, non-verbal forms of communication have to be considered first and foremost in the context of recognizing their potential aesthetic function, for example when characterising protagonists or staging character constellations. Particularly with regard to the use of drama texts, lessons should have a drama-pedagogical approach as their basis: only through acting out parts of a play can students realise that characters in a theatre play are not simply constructed through what they say, but also through how they say what they say and through the actions they perform while speaking. In order to focus learners' attention on these aspects of communication, it is not necessary to stage an entire play. Instead, a number of techniques of 
interpretation using short scenes can be useful (cf. Nünning/Surkamp 2010: 180ff.):

- Reading out loud: this highlights the acoustic dimension of a dramatic text. In addition, the method can reveal other linguistic levels of meaning, which might not be noticed when students only read the text silently.

- Scenic Reading: reading is combined with simple means of staging the text; the depicted situation is acted out through gestures and the movement of the actors who are reading the text.

- Acting out a scene: experimenting with different attitudes expressed while speaking, gestural and mimic forms of expression, body language (different postures adapted while walking, standing and sitting) and spatial arrangements (sitting or standing near to or far from each other, with or without eye contact, with or without body contact), the learners explore and practise how the characters behave, how they relate to each other, how they speak to each other and how they act in unison or in conflict with each other.

- Building a freeze frame: offers learners the opportunity to depict the central conflict of a drama by using relevant postures, gestures, mimic, body contact or distance as well as the direction of gazes.

Just as the integration of non-verbal communication into the teaching of culture should be organised in a mix of phases of acting and of reflecting, in a similar way sensitising learners to the significance of non-verbal communication when working with literary texts also requires such alternations.

It is especially productive to discuss the effect a scenic representation has on fellow students watching it. A considerable advantage of drama activities is the interaction of production and reception (cf. Schewe 1993: 5f.; Brekle 1995: 116). Since learners are simultaneously observers and actors, teachers should make use of the opportunity to discuss the effects students intended to achieve with their non-verbal behaviour while acting and to compare them to the effects they did actually achieve. Students watching the acting can be given observation tasks to this end. It is also important for them to watch out for the interplay of verbal and non-verbal signs, which is crucial for the overall effect of a drama activity.

\section{Conclusion}

The last example in particular shows that the dividing line between the teaching of language, literature and culture is not as clear-cut as it might appear when it comes to the integration of non-verbal communication in foreign language teaching. This, however, is really less of a problem than it is an advantage: language, literature and culture are closely intertwined and show a variety of 
overlapping aspects so that these different fields should, ideally, be combined in the classroom.

The overall aim of a pedagogy of non-verbal communication should be to sensitise the students to the potential effects of non-verbal phenomena in communication - both in formal and everyday conversations, in intercultural relationships and in literary texts. It is for this reason that we should shift away "from the competence-performance dichotomy and toward a perspective that embraces the importance of language in use - that is, how language is contextually situated in interaction" (Gullberg/McCafferty 2008: 134). One way of achieving this is to follow a drama-based approach in the foreign language classroom.

\section{Bibliography}

Abercrombie, David (1968): Paralanguage. In: British Journal of Disorders of Communication 3, 55-59

Argyle, Michael (1972): Non-verbal Communication in Human Social Interaction. In: Hinde, Robert A. (ed.): Non-verbal Communication. Cambridge: Cambridge UP, 243-269

Argyle, Michael (2002 [1979]): Körpersprache und Kommunikation. Das Handbuch zur nonverbalen Kommunikation. Paderborn: Junfermann Birdwhistell, Ray L. (1955): Background to Kinesics. In: ETC 13, 10-18 Bouchara, Abdelaziz (2009): Zum Erwerb interkultureller Kompetenz am Beispiel der Proxemik. In: Zielsprache Deutsch 36/2, 3-29

Brekle, Wolfgang (1995): Didaktische Überlegungen zum darstellenden Spiel im Deutschunterricht. In: Deutschunterricht 48/3, 114-121

Burgoon, Judee K. et al. (1989): Nonverbal Communication. The Unspoken Dialogue. New York: Harper \& Row

Common European Framework of Reference for Languages. Learning, Teaching, Assessment.

http://www.coe.int/t/dg4/linguistic/source/framework_en.pdf (Accessed 16 January 2015)

Crystal, David (1974): Paralinguistics. In: Sebeok, Thomas A. (ed.): Current Trends in Linguistics. Vol. 12. Den Haag: Mouton, 265-295

Culham, Cameron R. (2002): Coping With Obstacles in Drama-Based ESL Teaching. A Nonverbal Approach. In: Bräuer, Gerd (ed.): Body and Language. Intercultural Learning Through Drama. London: Ablex, 95-112

Ekman, Paul; Friesen, Wallace (1969): The Repertoire of Nonverbal Behavior: Categories, Origins, Usage and Coding. In: Semiotica 1, 49-98

Elis, Franziska (2015): Mit dramapädagogischen Methoden sprachliche und kommunikative Kompetenzen fördern. In: Hallet, Wolfgang; Surkamp, Carola (eds.): Handbuch Dramendidaktik und Dramapädagogik im Fremdsprachenunterricht. Trier: WVT, 89-115. 
Eßer, Ruth (2007): Körpersprache in Babylon. In: Krumm, Hans-Jürgen (ed.): Bausteine für Babylon. Sprache, Kultur, Unterricht. München: iudicum, 320-332

Gudykunst, William B.; Kim, Young Yun (1997 [1984]): Communicating with Strangers. An Approach to Intercultural Communication. Reading, MA/Menlo Park, CA: Addison-Wesley

Gullberg, Marianne; McCafferty, Steven G. (2008): Introduction to Gesture and SLA. Toward an Integrated Approach. In: Studies in Second Language Acquisition 30/2, 133-146

Hall, Edward T. (1966): The Hidden Dimension. New York: Doubleday

Hinner, Michael B. (1998): The Importance of Intercultural Communication in a Globalized World. http://ideas.repec.org/p/fth/freiba/98-6.html (Accessed 16 January 2015)

Jakobson, Roman (1960): Closing Statement. Linguistics and Poetics. In: Sebeok, Thomas A. (ed.): Style in Language. Cambridge, Mass.: MIT Press, 350-377

Kao, Shin-Mei; O'Neill, Cecily (1998): Words into Worlds. Learning a Second Language through Process Drama. Westport, CT: Ablex

Karbowska-Hayes, Suzanne (1984): Drama as a Second Language. A Practical Handbook for Language Teachers. Cambridge: National Extension College

Kendon, Adam (2004): Gesture. Visible Action as Utterance. New York: Cambridge UP

Knabe, Kristin (2007): Fremdsprachen effektiver lernen mit Gestik. Zur Theorie und Praxis von Gestik in der Fremdsprachendidaktik. Frankfurt a. M.: Lang Korte, Barbara (1993): Körpersprache in der Literatur. Theorie und Geschichte am Beispiel englischer Erzählprosa. Tübingen: Francke

Maley, Alan; Duff, Alan (2001): Drama Techniques in Language Learning. A Resource Book of Communication Activities for Language Teachers. Cambridge: Cambridge UP

Matthias, Bettina (2007): 'Show, don't tell!' Improvisational Theater and the Beginning Foreign Language Curriculum. In: Scenario 1/1, 56-69

Müller, Frank (1992): Dialog zwischen Text und Untertext. Theaterspielen als Sprechhandeln. In: Diskussion Deutsch 23/126, 365-374

Müller, Thomas (2008): Dramapädagogik und Deutsch als Fremdsprache. Eine Bestandsaufnahme. Saarbrücken: VDM

Nünning, Ansgar; Surkamp, Carola (2010): Englische Literatur unterrichten 1. Grundlagen und Methoden. $3^{\text {rd }}$ ed. Seelze-Velber: Kallmeyer-Klett

Özkul, Senem (2012): Speaking foreign body language. In: Praxis Fremdsprachenunterricht Englisch 9/5, 16-17.

Poyatos, Fernando (1983): New Perspectives in Nonverbal Communication. Oxford: Pergamon 
Reimann, Daniel (2000): Französisch durch Gesten. Bausteine einer Didaktik der nonverbalen Kommunikation. In: Französisch heute 1, 68-82

Reimann, Daniel (2008): Nonverbale Kommunikation im Spanischunterricht und interkulturelles Hör-/Sehverstehen. In: Hispanorama 121, 93-97

Reimann, Daniel (2012): Nonverbale Kommunikation zum Thema machen. Sprach- und kulturraumspezifische Gesten im Fremdsprachenunterricht. In: Pädagogik 64/10, 36-39

Rothwell, Julia (2011): Bodies and Language. Process Drama and Intercultural Language Learning in a Beginner Language Classroom. In: RiDE: The Journal of Applied Theatre and Performance 16/4, 575-594

Scherer, Klaus R. (1980): The Functions of Nonverbal Signs in Conversation. In: Giles, Howard; St. Clair, Roger (eds.): The Social and Psychological Contexts of Communication. Hillsdale: L. Erlbaum, 225-244

Schewe, Manfred (1993): Fremdsprache inszenieren. Zur Fundierung einer dramapädagogischen Lehr- und Lernpraxis. Oldenburg: Didaktisches Zentrum der Universität Oldenburg

Strasser, Margareta (2008): Verständigungsstrategien bei sehr geringen Sprachkenntnissen. Eine explorative Studie zur Kommunikation unter Bedingungen der Interkomprehension. Wien: Praesens

Surkamp, Carola (2012): Literarische Texte im kompetenzorientierten Fremdsprachenunterricht. In: Hallet, Wolfgang; Krämer, Ulrich (eds.): Kompetenzaufgaben im Englischunterricht. Grundlagen und Unterrichtsbeispiele. Seelze-Velber: Kallmeyer-Klett, 77-90

Tomalin, Barry; Stempleski, Susan (1993): Cultural Awareness. Oxford: Oxford UP.

Tselikas, Elektra I. (1999): Dramapädagogik im Sprachunterricht. Zürich: Orell Füssli.

Waegner, Heinrich (2003): Theaterwerkstatt. Kommentierte Wege vom Warm-up bis zur Spielvorlage. Stuttgart: Klett

Zephaniah, Benjamin (1999): Face. London: Bloomsbury. 